\title{
Construction on Network Resources of Ideological and Political Education for University
}

\author{
Lihui Li \\ College of Marxism, Bohai University, Jinzhou, 121013, China \\ Ilh5567@163.com
}

Keywords: university; ideological and political education; network resources; system construction

\begin{abstract}
Ideological and political education network resources to expand the space of the main body of education, the ideological and political education from the "real space" to "virtual space", and promote the reform and development of ideological and political education in universities. First, from four aspects of the problem, innovation, security and development, study the necessity of network resource construction in university ideological and political education, and then, the research from the user layer, function layer and data layer to constitute the ideological and political education network resource system structure; Finally, from the five aspects of the security system, education resources, the use value, the basic principle and the resources allocation, the research has studied the university ideological and political education network resources construction strategy. The research results of this paper have solved the core problem of the construction of ideological and political network resources in universities. It also has a very good reference function to other subjects.
\end{abstract}

\section{Introduction}

Network teaching resources is the premise and basis for the development of network education, with the gradual expansion of network education, network teaching resources are increasingly rich, effective management of teaching resources become the key to carry out network education. To strengthen the management of teaching resources, improve the utilization of teaching resources, and promote the teaching resources to better serve the practical teaching system. The resources of ideological and political education in a certain class of society, is incorporated into the ideological and political education activities in the development, utilization and management, and promote the purpose of ideological and political education. ideological and political education resources is the basis of ideological and political education activities. ideological and political education resources will not spontaneously produce, only through a certain way to build and use, to play a proper value. To find out the new function of the resources of ideological and political education, and to explore the potential of ideological and political education resources, to improve the quantity, quality and efficiency of ideological and political education resources. ideological and political education resource is an important part of the national political resources. It is the political consensus that the political body can be used to carry out ideological and political work [1]. The resources of ideological and political education have three meanings. First, the ideological and political education resources must be produced and exist in a certain social and historical conditions. Second, ideological and political education resources must have the information, function and value of ideological and political education. Third, the ideological and political education resources must be integrated into the ideological and political education activities [2].

With the development of information technology, the network has penetrated into every aspect of social life, especially the network technology is widely used in higher education. Network teaching has the characteristics of resource sharing, and it is not restricted by time space, so it expands the scale of education, improves the teaching effect, promotes the reform of education, and changes the traditional teaching mode and method, so as to expand the new space for the ideological and political education in universities, and promote the development of ideological and political education. Network resource construction is very important to the ideological and political 
education in universities, there is no rich network resources, the ideological and political education resources in universities is not complete. With the implementation of the new national education quality project, the construction of ideological and political education resources in universities will become more and more important.

\section{Necessity of Construction}

The process of developing the ideological and political education in universities is the process of obtaining, selecting and spreading information. It is the process of using correct, rich and vivid information, which influences the process of the students' idea, value orientation, thinking mode, behavior mode and mental state. Therefore, the emergence of the network in the field of education, will give the university ideological and political education means, ways and results of great changes. ideological and political education network resource construction is a manifestation of the ideological and political education in universities to adapt to the development of modern science and technology, with the characteristics of different traditional ideological and political education, it is a combination of computer network and ideological and political education in universities. The necessity of constructing the network resources of ideological and political education in universities is as follows [3-5]:

(1) Effectively solve the problem of the ideological and political education in universities in the era of network information. Information network era of open features, so that ideological and political education in college students' thinking in the growing space in the dominant position suffer the serious impact. On the one hand, the mass of network information "drowned" the ideological and political education information, the influence of the role of ideological and political education; On the other hand, college students take a lot of time to the network, and the degree of participation of the ideological and political education activities decreased. To strengthen the construction of network resources in ideological and political education is conducive to solving the above problems, and to establish the central position of the ideological and political education in the information network era.

(2) Network resource construction is the innovation of ideological and political education under the network culture environment. We must strengthen the construction of the campus network, make the network become an important means to carry forward the main melody and carry out the ideological and political education. According to the new changes of the students receiving the information, the construction of the campus network is to strengthen the construction of the campus network, and be good at using the Internet and other modern media, the ideological and political education content of organic integration, carry out lively Network ideological and political education, enhance the attraction and appeal of the network ideological and political education, the formation of network ideological and political education work system, firmly grasp the initiative of network ideological and political education.

(3) Network resource construction is an important guarantee of ideological and political education. Information is an important material carrier of knowledge culture in the network, which is the material basis of ideological and political education, so the construction of network resources is the material guarantee of ideological and political education informationization; ideological and political education resources in the network storage and sharing, breaking the traditional resources in time and space and geographical limitations, therefore, the construction of network resources is the ideological and political education environment guarantee; information resource replication costs low, access to convenient and sharing features, therefore, the construction of network resources is to promote the effectiveness of ideological and political education.

(4) Network resource construction is to meet the needs of the development of college students in the information age. ideological and political education can help college students establish correct outlook on life and values. The differences of College Students' personality are obvious, the traditional political teaching can not meet the development of personality, ideological and political education must conform to the characteristics of the times. Therefore, the full integration of ideological and political education network resources, enhance the learning of the subject, the 
cultivation of students' innovative awareness and ability to play the students' autonomy and initiative to meet the needs of students' personalized development.

\section{Composition on System}

Ideological and political education resources are rich and varied, and can be divided into different categories according to different standards. According to material and spiritual standards can be divided into material resources and spiritual resources, according to the composition of resources can be divided into natural resources and social resources, according to the standard of time can be divided into the traditional resources, real resources and future resources. Although the standards are not the same, the contents of the contents are generally consistent."Modern distance education resource construction technology standard" points out that teaching resources construction can have four levels of meaning [6], one is the material teaching resources construction, mainly divided into four major categories, namely the title, library, courseware library and case library; two is the construction of network curriculum library; three is the development of education resources management system; four is the development of general remote teaching system support platform. In these four levels, the construction of network curriculum and material teaching resources is the focus and core, the third and fourth levels are the tools of the construction, the network curriculum and material resources of the specific content of the ever-changing, the formation of many different characteristics, the corresponding management system and teaching system must adapt to this form of change, and make full use of their characteristics. According to the requirements of the modern distance education resources construction technology standard, combining with the actual needs of the ideological and political network resources, the network resources system of the ideological and political education in universities is composed of three levels, namely the user layer, function layer and data layer, as shown in Fig. 1.

(1) User layer. Including System administrator, Students, Teachers, Other personnel in school and Social public. System administrator, With full authority, responsible for the operation and maintenance of the system; Students is the direct service object of network resources, using the network resources to learn, but also to collect their own production of resource storage; Teachers, To guide students to learn, but also has the resources storage, resource audit, resource publishing and resource collection and other rights; Other personnel in school, Including teaching department staff, students in charge of departments and personnel, etc.; Social public, access to network resources through the Internet, but the smaller, only access to some of the open resources.

(2) Functional layer. Provide the relevant functions of the system, including the operation function and resource management functions, etc.. Operating functions for all types of users directly use, core functions include Resources warehousing, Resources audit, Resources release, Resources use and Resources solicitation and so on. Non core functions include system maintenance, data maintenance, operation management and resource exchange, resource management functions for the management of all kinds of resources, including Media material management, Test questions management, Network courseware management, Case management, Document literature management, Network course management and Other resources management and so on.

(3) Data layer. Provides 7 kinds of network resources storage. Among them, Media material database, refers to the dissemination of network resources of the basic material unit, can be divided into five categories of text, image class material, etc.; Test questions database, in accordance with certain educational measurement theory, in the computer system to achieve the subject of the collection, is based on the establishment of a mathematical model of educational measurement tool; Case database, is a representative event or phenomenon that has practical significance and teaching significance; Network courseware database, to one or a few knowledge points, the implementation of a relatively complete teaching of auxiliary teaching software, can run in the standard browser; Document literature database, store the corresponding educational policies and laws, etc.; Other resources database, to store the other resources of the above 6 kinds of resources. 


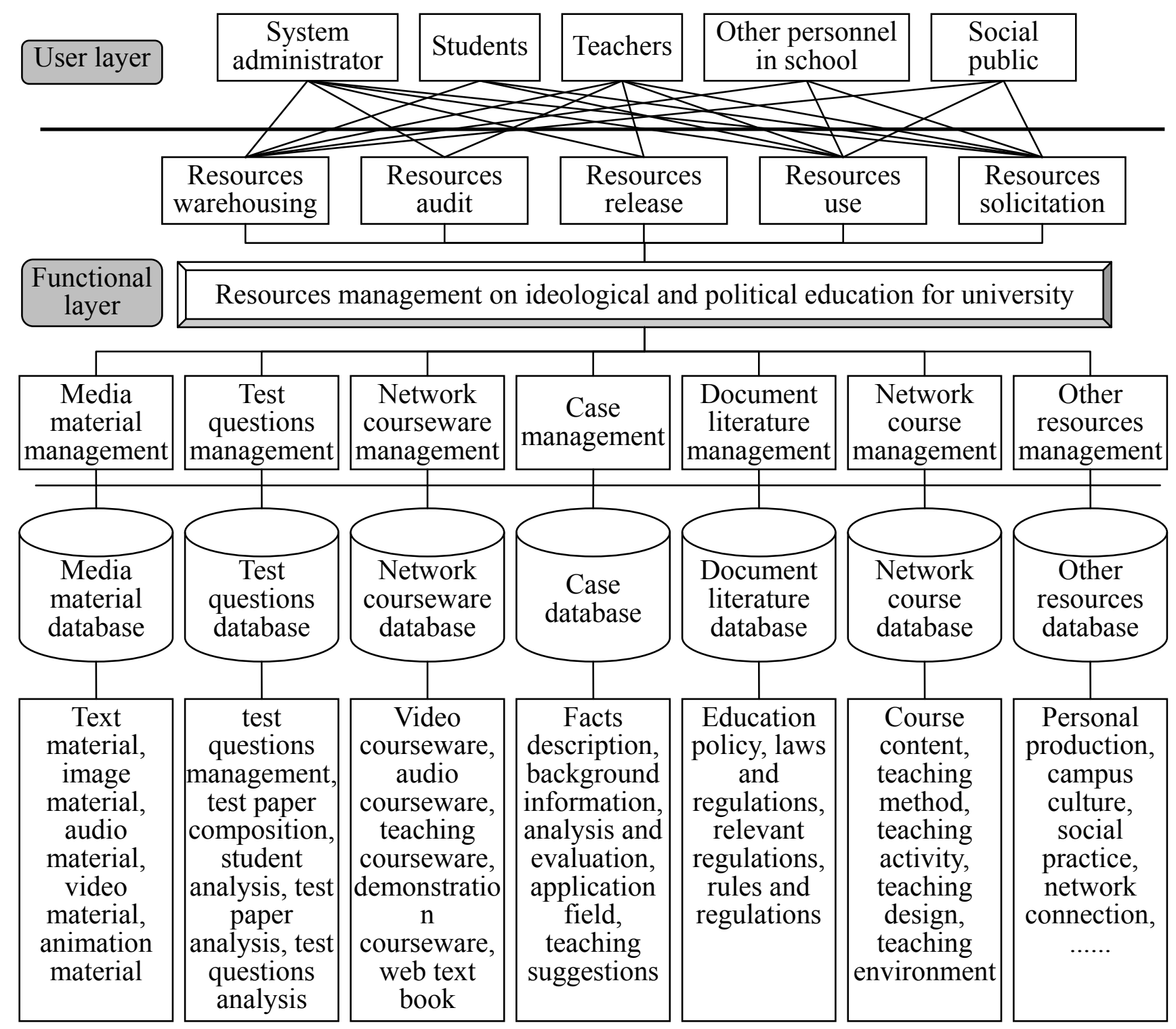

Data layer

Fig. 1. Composition on network resources of ideological and political education for university

\section{Strategy of Construction}

Make full use of network information technology, the maximum use of network resources, to provide students with a variety of network education resources, in line with the objective requirements of the ideological and political education in universities in china. In the construction process to follow the following strategies [7-9]:

(1) Sound ideological and political education network resources construction of the security system. Including leadership system, team system, network system, system and theoretical system. Among them, the leadership system, the establishment of network resource construction leading group, the integration of the functional departments to play a leading role; It is a new task to construct the network resource, which is the basic material of the network resource construction, the system of the campus network, the system, the establishment of a sound regulatory system, the guarantee of the network information, the theoretical system, the ideological and political education network resource construction is a new work, which needs scientific theoretical guidance.

(2) Fully tap the ideological and political education resources in the internet. As a new tool of information media, Internet has become an important channel for college students to acquire knowledge and information. All kinds of information on the Internet freely enter and read, for the ideological and political education resources to enter the Internet provides a convenient, but also for 
students to easily browse the content of ideological and political education to provide practical feasibility. The development and popularization of the network expands the space and channel of ideological and political education, and makes full use of modern means, and the resources of ideological and political education in the Internet. To speed up the process of the construction of network resources in the ideological and political education in universities.

(3) Promote the use value of resources based on actual needs. Fully meet the needs of the main body of education. The "main body" refers to the network ideological and political education, as the main body of the information dissemination, as well as the object of education information receiver. Resource construction should be adapted to the development of educational content, methods, and educational ideas, and to meet the needs of different education and communication carriers to meet the needs of different resources. The construction accords with the resources of the network reading habits of the main body of education, and constantly enrich the theoretical literature in the network information resources, and facilitate the network reading of the education object.

(4) We must insist on the basic principles of the construction of network resources in the ideological and political education. One is that the combination of ideological and political education of traditional resources and network resources, the traditional resources is a valuable experience, must be combined with the network resources, two is to adhere to the principle of active and guiding principle, the initiative to spread the ideological and political education information to implement education, guide students to understand and solve practical problems. The three is to adhere to the principle of combining scientific and adaptive, development of College Students' physical and mental characteristics and knowledge structure of the network resources, and the use of scientific thinking on the network resources.

(5) Improve the evaluation and feedback mechanism to optimize the network resource allocation. On the one hand, we establish the monitoring mechanism of the network resources of the ideological and political education, so as to get the use of the resources and find the problems. On the other hand, the establishment of a qualitative and quantitative evaluation mechanism, as well as an effective feedback mechanism. On the existing ideological and political education network resources for investment costs, production efficiency and utilization rate of the evaluation, according to the evaluation results of classification, the efficiency is low and the utilization rate is not high resources for optimization, optimization and then into the next round of evaluation, and ultimately will be the evaluation of the lower resources out of the system.

\section{Conclusion}

The network resources of ideological and political education in universities is the construction of the University as the main body, in the campus network, for the college teachers and students, for the implementation of ideological and political education. Network resource is a kind of information resource, and it has a very strong goal to be used, and it has a very strong target; Different information has different value in different users, which is integrated, and the retrieval and utilization is not restricted by time, space, language, region, etc.. ideological and political education network resources is an important part of education resources, is the basis of network ideological and political education for college students, is the important carrier of ideological guidance, political education and behavior of college students in the network virtual group directly carried out in [10].To deepen the rational understanding of the network resources of the ideological and political education, and to strengthen the construction of network resources is the objective requirement of enhancing the effectiveness of the ideological and political education in the information age. The research content of this paper is to solve the important problem of network resource construction, which has important guiding significance to the construction of ideological and political education resources in universities. 


\section{References}

[1] G. Wang, "Correctly deal with the relationship between the development and utilization of the resources of Ideological and Political Education," Studies in Ideological Education, vol. 27, no. 5, pp. 16-19, 2015.

[2] Q. Chen, "On the definition of Ideological and political education resources," China Adult Education, vol. 16, no. 19, pp. 28-29, 2007.

[3] L. M. Chai, "On the Great Significance of Ideological Education about the Network in College," journal of Fuling Teachers College, vol. 19, no. 4, pp. 103-106, 2003.

[4] L. Y. Sun, "Network culture construction and management thought and innovation of Ideological and political education in universities," Leading Journal of Ideological \& Theoretical Education, vol. 19, no. 2, pp. 95-99, 2012.

[5] X. L. He, J. X. Zhang, "Research on the construction of information resources of Ideological and Political Education under the network environment," Studies in Ideological Education, vol. 25, no. 9, pp. 56-60, 2013.

[6] Baidu library, "Technical specification on construction of modern distance education resources," http://wenku.baidu.com/view/fb5263afdd3383c4bb4cd237.html, 2015-8-14.

[7] S. B. Lei, Q. H. Chen, "On the way of social education of Ideological and political education in Colleges and Universities: the social resources of Ideological and political education in Colleges and Universities," Journal of Hubei University for Nationalities (Philosophy and Social Sciences), vol. 30, no. 2, pp. 137-139, 2012.

[8] S. S. Xie, "Research on the online teaching resource construction of college ideological and political theory course," Master's degree of Liaoning University of Technology, 2014.

[9] G. B. Zhao, M. Lan, "Fundamental Principles and Practical Ways of Integrating and Developing Ideological and Political Education Network Resources in Vocational Colleges," Journal of Wuxi Institute of Commerce, vol. 15, no. 1, pp. 55-57, 2015.

[10] F. Y. Li, X. Yang, "Analysis on the construction of network ideological and political education resources in universities," Education Exploration, vol. 31, no. 8, pp. 130-131, 2011. 